\title{
ENERGI POTENSIAL PEGAS DALAM KONSTRUKSI BALOK SEDERHANA BERBAHAN BETON BERTULANG
}

\author{
Oleh : \\ I Gusti Ngurah Eka Partama \\ Dosen Program Studi Teknik Sipil Universitas Ngurah Rai Denpasar
}

\begin{abstract}
ABSTRAK
Suatu benda atau material selalu memiliki massa yang merupakan komponen terpenting dari energi. Nilai energi akan ditentukan oleh massa, dimensi dan jarak dari permukaan bumi. Dimensi terpasang harus efektif dan efesien yang dimaksudkan agar konstruksi aman dalam memikul beban rencana dan biaya yang dibutuhkan tidak berlebih atau tidak boros. Kekuatan bahan adalah pertimbangan utama dalam menentukan kemampuan pikul dari suatu elemen struktur. Kekuatan bahan ditentukan oleh jenis material dan dimensi dari elemen struktur dimaksud. Kemampuan pikul suatu elemen struktur ditentukan oleh kemampuan elemen struktur untuk menyediakan energi potensial pegas yang juga dipengaruhi oleh jenis material dan dimensi elemen struktur. Kemampuan pikul suatu elemen struktur akan diindikasikan oleh nilai tengangan maksimum yang terjadi pada setiap bagian penampang balok dan nilai lendutan atau defleksi dari elemen struktur yang dimaksud. Suatu model struktur balok sederhana dua tumpuan bahan beton bertulang, bentang $10 \mathrm{~m}$, dikerjakan beban terpusat 10 ton dan beban merata penuh $2 \mathrm{t} / \mathrm{m}$. Suatu analisa diperlukan untuk menentukan dimensi balok sehingga mampu memikul beban rencana konstruksi balok sederhana model tersebut. Jumlah nominal energi yang dibutuhkan untuk memikul beban rencana pada konstruksi balok sederhana model dapat dihitung berdasarkan dimensi yang telah ditentukan. Hasil perhitungan mendapatkan model struktur balok sederhana dua tumpuan bahan beton bertulang, bentang $10 \mathrm{~m}$, beban terpusat 10 ton dan beban merata penuh $2 \mathrm{t} / \mathrm{m}$ dimensi yang paling efektif dan efesien yang dapat digunakan adalah $45 / 90 \mathrm{~cm}$. Energi potensial pegas yang dimanfaatkan sehingga mampu memikul beban dalam konstruksi tersebut sebesar $3,74 \mathrm{~kJ}$.
\end{abstract}

Kata kunci : Balok sederhana, beton bertulang, dimensi, energi potensial pegas

\begin{abstract}
An object or material always has a mass which is an important component of energy. The energy value will be determined by the masses, dimensions and distance from the Earth's surface. Mounted dimensions must be effective and efficient which is intended to carry the load safely in construction plans and costs are not excessive or wasteful. Strength of materials is a major consideration in determining the ability to bear of a structural element. The strength of the material is determined by the type of material and the dimensions of the structural element in question. The ability to endure a structural element is determined by the ability of the structural elements to provide a spring potential energy which is also affected by the type of material and dimensions of structural elements. The ability to endure a structural element will be indicated by the value of the maximum stresses that occurs in every part of the beam section and the value of deflection or deflection of the structural element in question. A model of a simple two-
\end{abstract}


beam structure of reinforced concrete pedestal material, spans $10 \mathrm{~m}$, carried 10 tons of concentrated load and distribute load $2 t / \mathrm{m}$. An analysis is needed to determine the dimensions of the beam so that it can bear the burden of a simple beam construction plan of the model. The nominal amount of energy required to bear the burden of the plan on the construction of a simple beam model can be calculated based on a predetermined dimension. The results of calculations to get a simple model of two support structure of reinforced concrete, spans $10 \mathrm{~m}$, concentrated 10 tons and distribute load $2 \mathrm{t} / \mathrm{m}$ dimension of the most effective and efficient that can be used is 45/90 cm. Spring potential energy is utilized so as to bear the burden in the construction amounted to 3.74 $k J$.

Keywords: simple beams, reinforced concrete, dimensions, spring potential energy.

\section{PENDAHULUAN}

\subsection{LATAR BELAKANG}

Material struktur secara umum yang sudah lazim diaplikasikan adalah bahan kayu, beton bertulang, baja, aluminium, plastic dan material komposit. Jenis material beserta dimensi atau ukuran elemen struktur yang dipasang sebagai komponen pendukung sistem struktur tergantung pada jumlah beban yang dipikul oleh elemen struktur yang bersangkutan dan sistem struktur yang direncanakan. Untuk struktur bangunan gedung sampai tingkat dua jenis material yang dimanfaatkan yaitu : kayu, baja atau besi dan beton bertulang, sedangkan untuk bangunan gedung tinggi (high rise building) material yang dominan digunakan adalah baja dan beton bertulang dengan sistem struktur statis tidak tentu (statically Indeterminate Structures), sedangkan untuk konstruksi jembatan menggunakan konstruksi material, kayu, baja, beton dengan sistem struktur statis tertentu (balok sederhana, simple beam) atau konstruksi statis tidak tentu.

Suatu benda atau material selalu memiliki massa yang merupakan komponen terpenting dari energi. Nilai energi akan ditentukan oleh massa, dimensi dan jarak dari permukaan bumi. Dimensi terpasang harus efektif dan efesien yang dimaksudkan agar konstruksi aman dalam memikul beban rencana dan biaya yang dibutuhkan tidak berlebih atau tidak boros. Kekuatan bahan adalah pertimbangan utama dalam menentukan kemampuan pikul dari suatu elemen struktur. Kekuatan bahan ditentukan oleh jenis material dan dimensi dari elemen struktur dimaksud. Kemampuan pikul suatu elemen struktur ditentukan oleh kemampuan elemen struktur untuk menyediakan energi potensial pegas yang juga dipengaruhi oleh jenis material dan dimensi elemen struktur. Kemampuan pikul suatu elemen struktur akan diindikasikan oleh nilai tengangan 
maksimum yang terjadi pada setiap bagian penampang balok dan nilai lendutan atau defleksi dari elemen struktur yang dimaksud.

Konstruksi bangunan sipil yang paling sederhana adalah konstruksi dua tumpuan. Jika suatu model struktur balok sederhana dengan beban rencana diberikan, maka harus ditentukan dimensi balok yang paling ekonomis untuk bisa memikul beban rencana tersebut dan berdasarkan dimensi tersebut dapat dihitung nilai nominal energi yang dapat tersimpan dan dimanfaatkan untuk memikul beban rencana.

\subsection{PERUMUSAN MASALAH}

Jika suatu model struktur balok sederhana berbahan beton bertulang diberikan dalam rangka untuk memikul suatu beban rencana dan untuk mengetahui nominal energi yang tersimpan dan dimanfaatkan, maka masalah yang harus diberikan solusinya adalah :

1. Berapakah dimensi balok yang harus dipasang sehingga mampu memikul beban rencana konstruksi balok sederhana model?

2. Berapakah nominal energi yang dibutuhkan untuk memikul beban rencana pada konstruksi balok sederhana model?

\subsection{TUJUAN PENULISAN}

Tujuan penulisan ini ini adalah :

1. Menentukan dimensi balok yang ekonomis untuk bisa memikul beban rencana

2. Menentukan nominal energi yang tersimpan dan dimanfaatkan untuk memikul beban rencana.

\section{TINJAUAN PUSTAKA}

\subsection{KONSTRUKSI BALOK SEDERHANA (SIMPLE BEAM)}

Konstruksi balok sederhana adalah konstuksi terdari dua tumpuan atau perletakan yaitu perletakan sendi dan rol. Konstruksi ini banyak diaplikasi pada konstruksi jembatan. Sebelum melakukan perhitungan Gaya-gaya, harus dilakukan perhitungan Reaksi Perletakan terlebih dahulu dengan persamaan Tiga Persamaan Keseimbangan yaitu : $\Sigma \mathrm{M}$ $=0, \Sigma \mathrm{V}=0$ dan $\Sigma \mathrm{H}=0$ (Setiawan, 2015). Gaya-gaya Dalam terdiri Momen Lentur (M), Gaya Lintang atau Gaya Geser (D) dan Gaya Aksial atau gaya Normal (N). Momen 
Lentur adalah gaya yang menyebabkan melenturnya elemen struktur yang merupakan hasil perkalian suatu gaya (Reaksi Perletakan dan Gaya Dalam) dengan suatu jarak ke suatu titik tinjau tertentu. Gaya lintang atau Gaya Geser adalah Gaya-gaya yang tegak lurus dengan sumbu batang dan Gaya Normal atau Gaya Aksial adalah gaya yang sejajar degan sumbu batang.

Untuk konstruksi statik tidak tentu dalam perhitungan Gaya Dalam dapat dilakukan setelah konstruksi statis tidak tentu diubah menjadi konstruksi statis tertentu dengan menentukan reaksi kelebihan (redundant) terlebih dahulu. Dalam analisa struktur ada beberapa metode yang digunakan untuk menghitung reaksi kelebihan yaitu : 1) Metode Gaya (force method) atau sering disebut Metode Konsistensi Deformasi, 2) Metode Perpindahan (displacement method) terdiri dari Metode Persamaan Tiga Momen (Metode Clapeyron), Metode Slope Deflection, Metode Distribusi Momen (Metode Cross, Metode Kani, Metode Takabeya), 3) Metode Kekakuan (Stiffness Method) (Setiawan, 2015) dan 4) Metode Elemen Hingga (Finite Element Method) adalah metode numerik untuk mendapatkan solusi persamaan diferensial, dimana proses inti metode ini adalah membagi problem yang kompleks menjadi bagian-bagian kecil sehingga solusi yang lebih sederhana dapat diperoleh. Solusi yang sederhana dari setiap elemen yang lebih kecil inilah dapat digunakan untuk memecahkan permasalahan struktur secara keseluruhan (Kosasih, 2012 ; Hadipratomo, et.al. 1985, ).

\subsection{DEFORMASI PADA BALOK}

Deformasi pada balok terdiri dari robahan panjang, putaran sudut (Rotation), lendutan (Deflection), Puntiran (Torsion) (Soemono, 1993).

\subsubsection{Robahan Panjang}

Robahan panjang yaitu perpanjangan atau perpendekan yang diakibatkan oleh Gaya Aksial atau Gaya Normal (gaya yang bekerja sejajar sumbu batang). Dalam Hukum Hooke dinyatakan robahan panjang $(\delta)$ yang terjadi berbanding lurus dengan panjang batang semula (L), gaya normal yang bekerja (P), berbanding terbalik dengan luas penampang $(\mathrm{F})$, berbanding terbalik dengan Modulus Elastisitas bahan (E) dari batang tersebut.

Dalam persamaan matematika robahan panjang $(\delta)$ dinyatakan dengan formula $\delta=\frac{P . L}{E . F}$. Jika disusun persamaan $\frac{\delta}{L}=\frac{P}{F} \cdot \frac{1}{E}$ dan jika $\frac{\delta}{L}=\varepsilon$ disebut regangan 
(strain) dan $\frac{P}{F}=\sigma$ disebut tegangan (stress), maka persamaan diatas dapat ditulis $\varepsilon=\sigma \cdot \frac{1}{E} \quad$ atau $\quad \sigma=\varepsilon . \mathrm{E}$.

\subsubsection{Putaran Sudut dan Lendutan}

Yang dimaksud dengan putaran sudut $(\boldsymbol{\theta})$ yaitu besarnya sudut yang dibentuk pada suatu titik antara sumbu batang setelah balok dibebani dengan sumbu batang sebelum balok dibebani.

Yang dimaksud dengan lendutan $(\boldsymbol{\Delta})$ yaitu jarak antara titik pada balok sebelum dibebani dengan setelah balok dibebani.

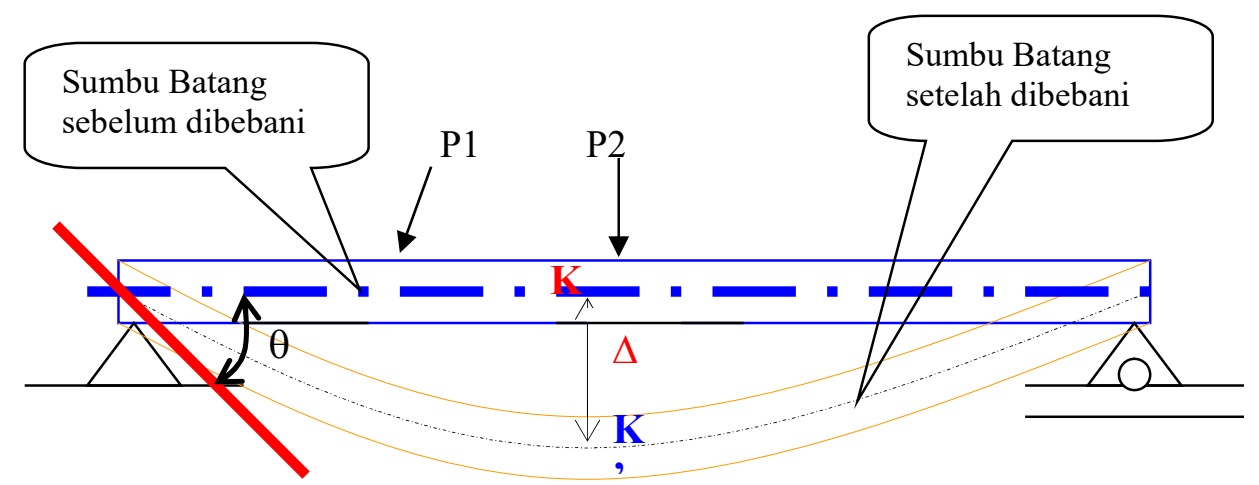

Gambar 2.1. Ilustrasi putaran sudut dan lendutan

Untuk nilai lendutan dan putaran sudut pada balok sederhana pada kasus pembebanan beban merata penuh dan beban terpusat seperti yang disajikan pada Tabel 1 .

Tabel 1. Deformasi pada balok sederhana (Cheng, 1998)

\begin{tabular}{|c|c|c|c|}
\hline 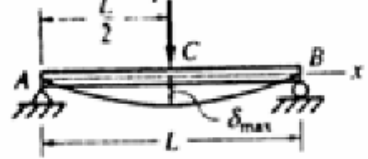 & $\delta_{\max }=\frac{P L^{3}}{48 E I}$ & $\theta_{\mathrm{A}}=\theta_{\mathrm{B}}=\frac{P L^{2}}{16 E I}$ & $\delta_{A C}=\frac{P X}{48 E I}\left(3 L^{2}-4 x^{2}\right)$ \\
\hline 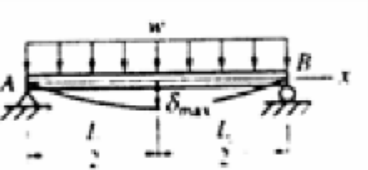 & $\delta_{\max }=\frac{5 w L^{4}}{384 E I}$ & $\theta_{A}=\theta_{B}=\frac{w L^{3}}{24 E I}$ & $\delta=\frac{w X}{24 E I}\left(L^{3}+x^{3}-2 L x^{2}\right)$ \\
\hline
\end{tabular}




\subsubsection{Puntiran}

Sebuah batang yang dikerjakan gaya torsi, maka pada dua titik pada lokasi penampang yang berbeda akan terjadi perputaran sudut relatif satu sama lain yang disebut dengan sudut puntiran yang dinotasikan dengan $\phi$ Penurunan Rumus untuk menentukan besarnya $\phi$ ditentukan berdasarkan pembahasan di bawah ini.

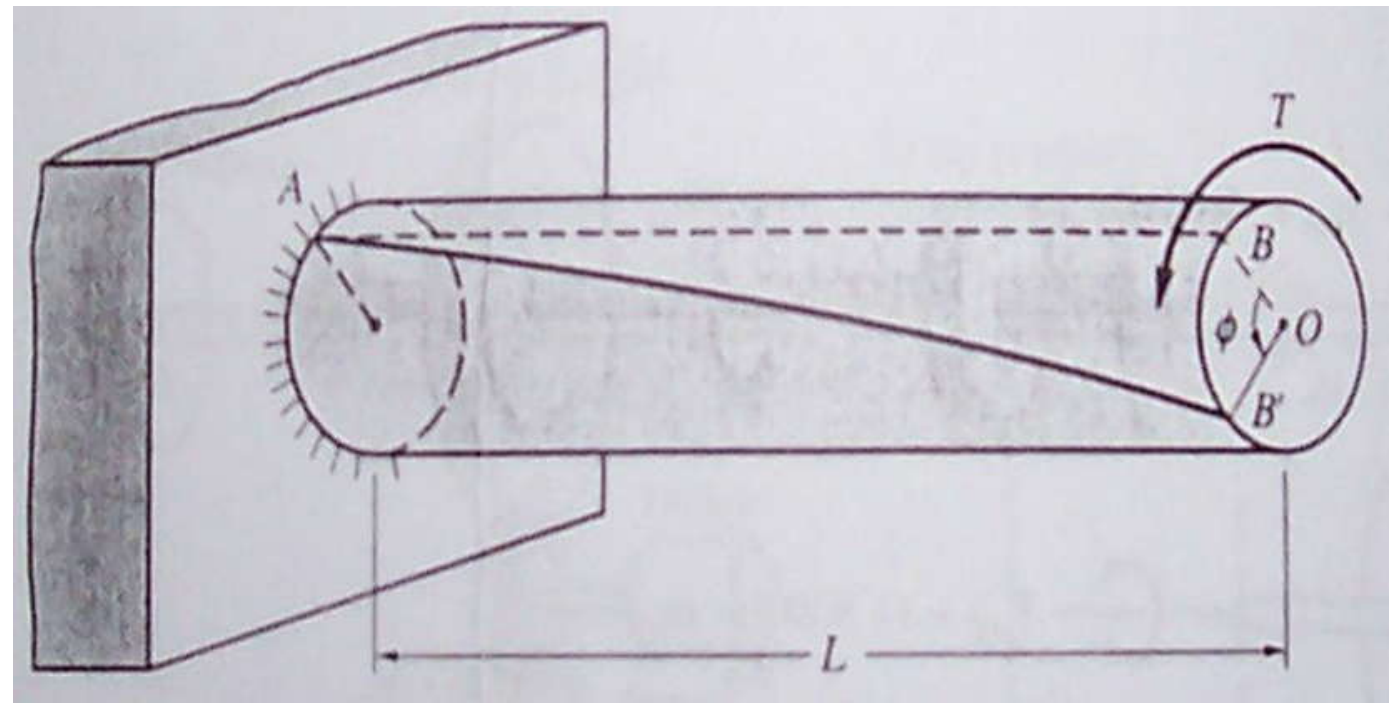

Gambar 2.2. Sebuah kantilever yang mendapat beban Torsi sebersar T

Dengan adanya puntiran maka unsur-unsur dalam penampang sepanjang bentang mengalami putaran sebesar $\phi$. Besarnya $\phi$ ditentukan sebagai berikut :

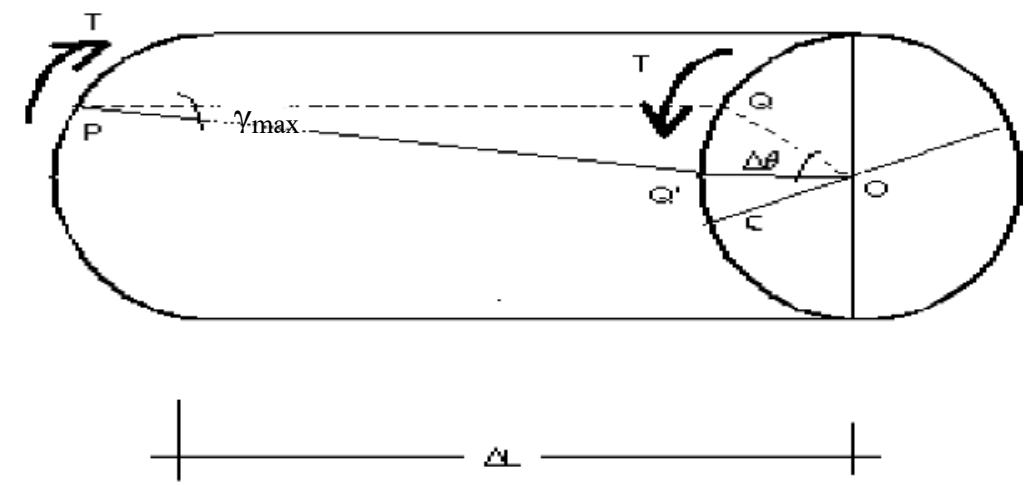

Gambar 2.3. Bagian balok sepanjang $\Delta \mathrm{L}$ yang mengalami puntiran 


$$
\text { Busur QQ' }=\gamma_{\max } \cdot \Delta \mathrm{L}=\mathrm{c} . \Delta \theta \rightarrow \Delta \theta=\frac{\gamma_{\max } \cdot \Delta L}{c}
$$

Untuk distorsi elastis pada batang yang mengalami puntiran, gaya geser maksimum dalam batas elastis dan menurut Hukum Hooke berlaku :

$$
\gamma_{\max }=\frac{\tau_{\max }}{G}=\frac{T . c}{I p \cdot G} ; \text { dengan } \mathrm{G}=\text { Modulus Geser }
$$

Dengan mensubstitusikan nilai $\gamma_{\max }$ ke persamaan $\Delta \theta$ didapat :

$$
\Delta \theta=\frac{\gamma_{\max } \cdot \Delta L}{c}==\frac{T \cdot c}{I p \cdot G} \cdot \frac{\Delta L}{c}=\frac{T}{I p \cdot G} \cdot \Delta L
$$

Untuk Torsi yang bekerja sepanjang $\mathrm{L}$ dari Suatu titik tetap akan berlaku :

$$
\theta=\sum \Delta \theta=\sum \frac{T}{I p \cdot G} \cdot \Delta L=\frac{T}{I p . G} \sum \Delta L ; \sum \Delta \mathrm{L}=\mathrm{L}
$$

Sehingga : $\theta=\frac{T \cdot L}{I p \cdot G}$, Dimana : $\theta=$ Putaran sudut torsi/puntir pada lokasi torsi dalam radian, $\mathrm{T}=$ Torsi (dalam $\mathrm{kgm}), \mathrm{L}=$ Panjang Batang dari ujung batang yang dianggap tetap (perletakan) ke lokasi Torsi $($ dalam $\mathrm{m}), \mathrm{Ip}=$ Inersia Polar $=\mathrm{Ix}+\mathrm{Iy}\left(\right.$ dalam $\left.\mathrm{m}^{4}\right)$ dan $\mathrm{G}=$ Modulus geser (tergantung jenis bahan, dalam $\mathrm{m}^{4}$ ).

\subsection{ENERGI POTENSIAL PEGAS PADA BATANG YANG DIBEBANI LENTUR}

Sebuah balok sederhana yang dibebani momen lentur murni $M$ pada setiap ujungnya akan menunjukkan garis defleksi beserta kelengkungannya sesuai Gambar 2.4.

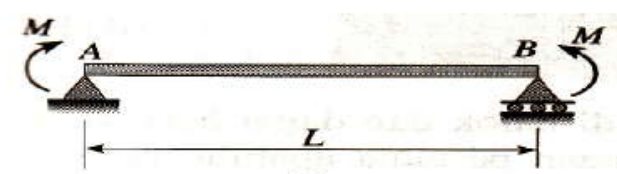

(a)

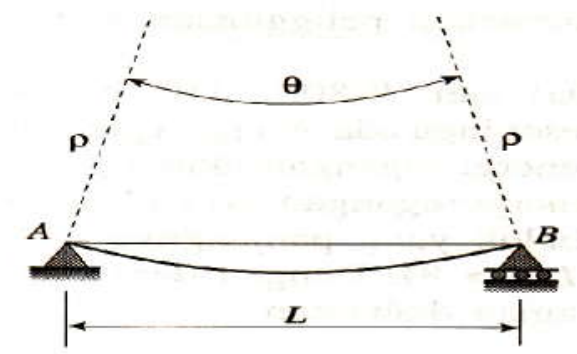

(b)

Gambar 2.4 Balok sederhana dengan beban lentur murni M pada setiap ujung 
Sudut $\theta$ yang dibatasi oleh busur ini sama dengan $L / \rho$, kelengkungan $\mathrm{k}=\mathrm{M} / \mathrm{EI}$. Untuk balok dalam kondisi elasitis berlaku Hukum Hooke dimana berlaku $k=\frac{1}{\rho}$ sehingga : $\theta=\frac{L}{\rho}=\frac{1}{\rho} \cdot L=k \cdot L=\frac{M}{E I} \cdot L=\frac{M L}{E I}$

Pada kondisi balok yang elastis hubungan antara momen $M$ dan sudut $\theta$ ditunjukkan secara grafis pada Gambar 2.5.

Energi potensial pegas yang tersimpan dalam balok tersebut adalah luasan kurva yang diarsir yaitu : $U=\frac{1}{2} \cdot \theta \cdot M=\frac{1}{2} \cdot \frac{M L}{E I} \cdot M=\frac{M^{2} L}{2 E I}$

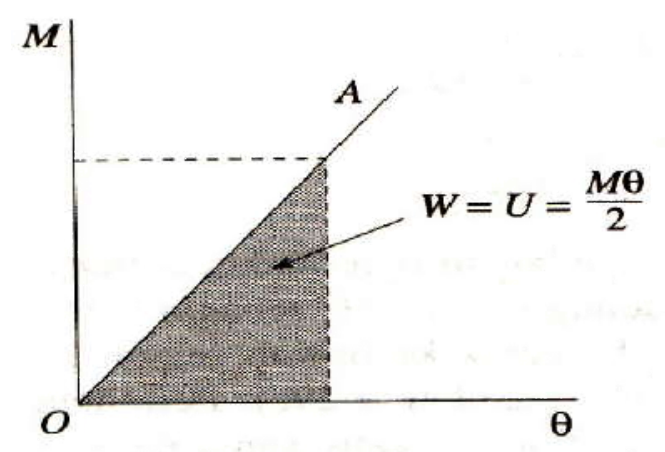

Gambar 2.5 Hubungan antara momen lentur dengan sudut kelengkungan

Karena $\theta=\frac{M L}{E I}$, maka $M=\frac{\theta E I}{L}$ dan energi yang tersimpan dalam balok dapat dinyatakan dalam : $U=\frac{\left\{\frac{\theta E I}{L}\right\}^{2} L}{2 E I}=\frac{\frac{\theta^{2} E^{2} I^{2}}{L}}{2 E I}=\frac{\theta^{2} E I}{2 L}$

Momen lentur yang bekerja pada balok bervariasi menurut variasi beban yang bekerja pada balok sehingga kondisi momen lentur murni pada pembahasan diatas harus disesuaikan dan solusi yang diambil dengan melakukan integrasi untuk seluruh panjang bentang balok (Gere, et.al.,2000).

Jika diambil pias panjang batang sebesar $\mathrm{dx}$ maka pias sudut $(\mathrm{d} \theta)$ dapat ditentukan sebesar $\mathrm{d} \theta=\mathrm{kdx}$ dan jika $\mathrm{k}=\frac{1}{\rho}=\frac{d \theta}{d x}=\frac{d^{2} y}{d x^{2}}$, maka $\mathrm{d} \theta=\frac{d 2 y}{d x 2} d x$ dan 
energi potensial pegas pada pias tinjauan dU dapat ditentukan sebesar $\quad d U=\frac{M^{2} d x}{2 E I}$ dan $\quad d U=\frac{(d \theta)^{2} E I}{2 d x}=\frac{E I}{2 d x}\left\{\frac{d^{2} y}{d x 2} d x\right\}^{2}=\frac{E I}{2}\left\{\frac{d^{2} y}{d x^{2}}\right\}^{2} d x$. Dengan mengintegrasikan persamaan-persamaan diatas untuk seluruh panjang balok, kita dapat menyatakan energi regangan yang disimpan di dalam balok dalam bentuk : $U=\int \frac{M^{2} d x}{2 E I}$ dan $U=\int \frac{E I}{2}\left\{\frac{d^{2} y}{d x^{2}}\right\}^{2} d x$. Momen lentur (M) pada balok dapat bervariasi sebagai fungsi dari x. Kita gunakan persamaan pertama apabila momen lentur diketahui dan persamaan kedua apabila persamaan kurva defleksi diketahui (Gere, et.al.,2000).

\section{PEMBAHASAN}

\subsection{MODEL STRUKTUR}

Suatu konstruksi jembatan yang direncanakan menggunakan konstruksi balok sederhana seperti model struktur yang disajikan pada Gambar 3.1. Konstruksi direncanakan sesuai beban rencana yang tercantum pada idealisasi struktur, berbahan beton bertulang dengan mutu K-250. Perencanaan akan menentukan dimensi yang efektif dan efesien serta akan dihitung berapa nominal energi yang dimanfaatkan sehingga bisa memikul beban rencana. Beban pada jembatan yang ditampilkan pada Gambar 3.1 hanya pemodelan saja. Untuk perencanaan teknis yang rinci harus mengikuti standar perhitungan pembebanan untuk jembatan.

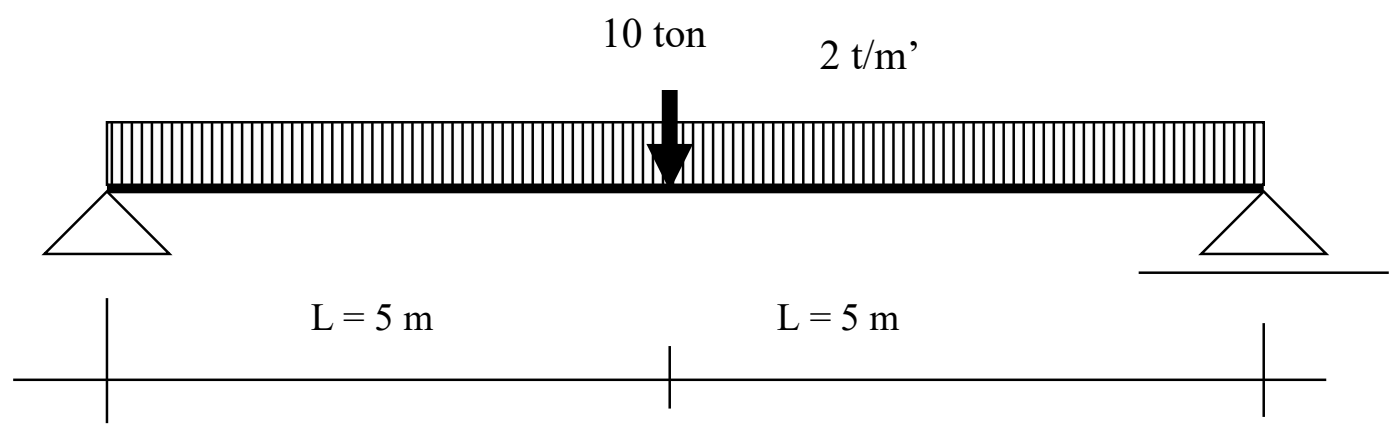

Gambar 3.1 Model struktur balok sederhana konstruksi jembatan beton bertulang 


\subsection{SYARAT-SYARAT DESAIN}

Untuk bisa memikul beban rencana, dimensi balok harus direncanakan sehingga tidak melampau nilai tegangan maksimum yang diperbolehkan pada penampang balok dan tidak melampau nilai lendutan maksimum yang diizinkan. Pada Peraturan Beton Bertulang Indonesia 1971 (PBI'71), disebutkan tegangan izin mutu beton K-250 $\left(\sigma^{\prime} \mathrm{bk}=250 \mathrm{~kg} / \mathrm{cm}^{2}\right)$ adalah $\sigma^{\prime} \mathrm{b}=0,33 \quad \sigma^{\prime} \mathrm{bk}=0,33.250=82,5 \mathrm{~kg} / \mathrm{cm}^{2}$ dan lendutan maksimum yang diizinkan sebesar $\bar{f}=1 / 250$ panjang bentang, sesuai ketentuan RSNI T-12-2004, tentang Perencanaan Struktur Beton Untuk Jembatan.

\subsection{PERENCANAAN DIMENSI}

Dimensi balok yang direncanakan berbentuk segi empat dan diambil tinggi penampang balok sama dengan 2 kali dimensi lebar balok $(\mathrm{h}=2 \mathrm{~b}$ atau $\mathrm{b}=1 / 2 \mathrm{~h})$ (Wang, et. al., 1987). Dimensi balok dihitung berdasarkan persyaratan tegangan dan persayaratan lendutan maksimum yang dijinkan kemudian dipilih dimensi yang memberikan keamanan terhadap dua persyaratan dimaksud.

Dimensi balok yang hitung berdasarkan tegangan maksimum yang diizinkan dihitung dengan rumus $\sigma=\frac{M}{W} ; \mathrm{M}=$ Momen lentur maksimum yang terjadi pada tengah bentang, $\mathrm{W}=$ Momen tahanan penampang, $\mathrm{M}=$ Momen ditengah bentang akibat beban $\mathrm{q}=2 \mathrm{t} / \mathrm{m}$ ' dan akibat beban $\mathrm{P}=10$ ton, $\mathrm{M}=1 / 8 \cdot \mathrm{q} \cdot \mathrm{L}^{2}+1 / 4 \cdot \mathrm{P} \cdot \mathrm{L}=1 / 8 \cdot 2 \cdot 10^{2}+1 / 4 \cdot 10 \cdot 10$ $=25+25=50 \mathrm{tm}=5.000 .000 \mathrm{kgcm}, \mathrm{W}=1 / 6 \cdot \mathrm{b} \cdot \mathrm{h}^{2}=1 / 6 \cdot \mathrm{b} \cdot(2 \mathrm{~b})^{2}=2 / 3 \cdot \mathrm{b}^{3}, \sigma^{\prime} \mathrm{b}=82,5$ $\mathrm{kg} / \mathrm{cm}^{2}, \quad 82,5 \geq \frac{5.000 .000}{2 / 3 . b^{3}}, \mathrm{~b} \geq \sqrt[3]{\frac{5.000 .000}{2 / 3.82,5}}=44,96 \mathrm{~cm}$ dipakai $\mathrm{b}=45 \mathrm{~cm}$, sehingga $\mathrm{h}=2 \mathrm{~b}=2.45=90 \mathrm{~cm}$. Jadi dimensi berdasarkan batasan nilai tegangan ijin beton adalah $45 / 90 \mathrm{~cm}$.

Dimensi balok berdasarkan pada lendutan maksimum yang diizinkan dihitung sebagai berikut : $\bar{f}=\frac{1}{250} \cdot L=\frac{1}{250} \cdot 1000=4 \mathrm{~cm}, \mathrm{q}=2 \mathrm{t} / \mathrm{m}^{\prime}=20 \mathrm{~kg} / \mathrm{cm}, \mathrm{P}=10$ ton $=$ $10.000 \mathrm{~kg}, \mathrm{f} ' \mathrm{c}=0,83.250=207,5 \mathrm{~kg} / \mathrm{cm}^{2}=20,75 \mathrm{MPa}, \mathrm{Ec}=$ Modulus Elastisitas Beton $=4700 \sqrt{\mathrm{f}^{\prime} \mathrm{c}}=4700 \sqrt{2} 2.75=21410 \mathrm{MPa}=214100 \mathrm{~kg} / \mathrm{cm}^{2}$ (Purwono, et. al., 2007, Wahyudi, et. al. 1997), $\mathrm{I}=$ Momen Inersia $=1 / 12 \cdot b \cdot h^{3}=1 / 12 \cdot b \cdot(2 b)^{3}=2 / 3 \cdot b^{4}$, $\mathrm{EI}=142733 b^{4}, \quad 4 \geq \frac{5}{384} \cdot \frac{q L^{4}}{E I}+\frac{1}{48} \cdot \frac{P L^{3}}{E I}=\frac{5}{384} \cdot \frac{20 \cdot 1000^{4}}{142733 b^{4}}+\frac{1}{48} \cdot \frac{10000 \cdot 1000^{3}}{142733 b^{4}}=$ 
$\frac{3284104}{b^{4}}, \mathrm{~b} \geq \sqrt[4]{\frac{3284104}{4}}=30.102 \mathrm{~cm}$ dipakai $\mathrm{b}=35 \mathrm{~cm}$, sehingga $\mathrm{h}=2 \mathrm{~b}=2.35=70$ $\mathrm{cm}$. Jadi dimensi berdasarkan batasan nilai lendutan adalah $35 / 70 \mathrm{~cm}$, sehingga dimensi yang digunakan sebagai pilihan terakhir untuk menentukan dimensi balok adalah penampang yang terbesar yaitu $45 / 90 \mathrm{~cm}$.

\subsection{JUMLAH ENERGI PADA BALOK SEDERHANA}

Jumlah energi yang tersimpan dan dimanfaatkan pada konstruksi balok sederhana model dihitung dengan formula umum : $U=\int \frac{M^{2} d x}{2 E I}$. Dari persamaan integrasi untuk energi tersebut dibutuhkan persamaan momen lentur untuk seluruh bentang yang dihitung dari konstruksi balok sederhana model dengan beban dan dimensi balok yang sudah direncanakan. Perhatikan Gambar 3.1. Mx $=$ Ra.x $-1 / 2 . q . x^{2}=150000 . x$ $-1 / 2.20000 \cdot \mathrm{x}^{2}=-10000\left(\mathrm{x}^{2}+15 \mathrm{x}\right), 0<\mathrm{x}<5$ (bentang $\overline{A C}$ ). Energi potensial pegas yang tersimpan pada sepanjang bentang $(\overline{A B}=\overline{A C}+\overline{B C})$ dihitung sebesar :

$$
\begin{aligned}
U= & 2 \int \frac{\left(-10000\left(x^{2}+15 x\right)^{2} d x\right.}{2 E I}=2 \int \frac{\left(10000^{2}\left(x^{4}+30 x^{3}+225 x^{2}\right) d x\right.}{2 E I} \\
& =2 \cdot \frac{10^{8}}{2 E I}\left[1 / 5 \cdot x^{5}+40 \cdot 1 / 4 \cdot x^{4}+225 \cdot 1 / 3 \cdot x^{3}\right]_{0}^{5}=\frac{10^{8}}{E I}\left[0,2 \cdot x^{5}+10 \cdot x^{4}+75 \cdot x^{3}\right]_{0}^{5} \\
& =\frac{10^{8}}{E I}\left[0,2 \cdot x^{5}+10 \cdot x^{4}+75 \cdot x^{3}\right]_{0}^{5}=\frac{2 \cdot 1875 \cdot 10^{12}}{E I}
\end{aligned}
$$

$100000 \mathrm{~N}$

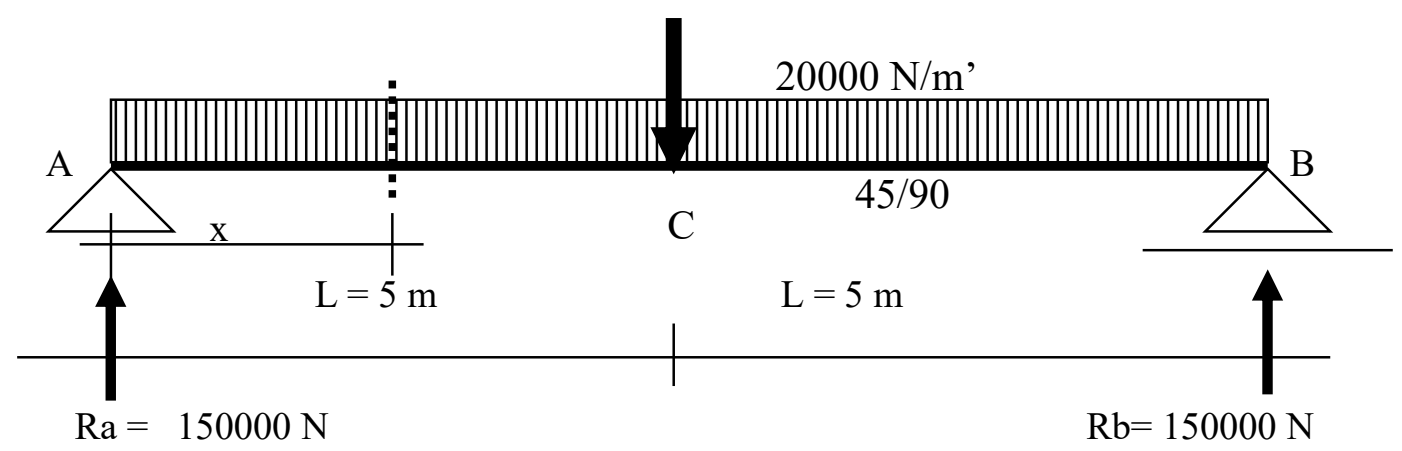

Gambar 3.2 Ilustrasi untuk menentukan persamaam momen 
Ec $\quad=214100 \mathrm{~kg} / \mathrm{cm}^{2}=2,1410.10^{10} \mathrm{~N} / \mathrm{m}^{2}, \mathrm{I}=1 / 12 \cdot 0,45 \cdot 0,90^{3}=2,734 \cdot 10^{-2} \mathrm{~m}^{4}$, Ec.I $=$ $5,853.10^{8} \mathrm{~N} \cdot \mathrm{m}^{2}$. Jadi energi potensial pegas yang dimanfaatkan pada konstruksi balok sederhana sesuai pembebanan pada model adalah sebesar :

$$
\mathrm{U}=\frac{2,1875 \cdot 10^{12}}{5,853 \cdot 10^{8}}=3.74 \cdot 10^{3} \text { Joule }=3.74 \text { kilo Joule }=3.74 \mathrm{~kJ} .
$$

Potensi energi yang tersimpan dalam suatu batang pastinya lebih banyak dari energi yang dimanfaatkan untuk memikul beban apabila struktur atau elemen struktur masih mampu memikul beban, artinya jika suatu konstruksi atau elemen struktur sudah gagal, berarti potensi energi yang dimiliki oleh struktur dan atau elemen struktur sudah tidak cukup untuk memikul atau mendukung beban yang dikerjakan pada struktur tersebut.

\section{SIMPULAN DAN SARAN}

\subsection{SIMPULAN}

Kesimpulan yang diambil dari hasil pembahasan berdasarkan model konstruksi balok sederhana adalah :

1. Dimensi penampang balok yang paling ekonomis untuk konstruksi balok sederhana dengan bentang $10 \mathrm{~m}$ dibebani beban merata $2 \mathrm{t} / \mathrm{m}$ ' dan beban terpusat ditengah bentang menggunakan balok beton bertulang K-250 adalah $45 / 90 \mathrm{~cm}$

2. Energi yang tersimpan dan dimanfaatkan untuk mendukung beban rencana dari balok beton bertulang K-250 berdimensi $45 / 90 \mathrm{~cm}$ sebesar 3,74 kJ

\subsection{SARAN}

Dalam tinjauan model balok sederhana asumsi yang dibangun terbatas pada prilaku balok sederhana dalam kondisi elastis linear, sehingga potensi energi yang dihitung hanya pada kondisi linear saja. Untuk menentukan energi potensial pegas yang lebih besar maka disarankan untuk meninjau perilaku elemen struktur sampai pada batas inelastis non linear. 


\section{DAFTAR PUSTAKA}

1. Anonimous, (1979), Peraturan Beton Indonesia 1971, NI-2 Cetakan ketujuh, Departemen Pekerjaan Umum dan Tenaga Listrik, Bandung

2. Anonimous. (2004). Perencanaan Struktur Beton Untuk Jembatan, Badan Standarisasi Nasional, Jakarta

3. Cheng, F. H., (1998), Statics and Strength of Materials ( $2^{\text {nd }}$ Edition), Glencoe/McGraw-Hill, New York

4. Gere, J. M. dan Thimoshenko, S. P., Bambang Suryoatmono, (2000), Mekanika Bahan, Jilid 2 Edisi Keempat, Penerbit Erlangga, Jakarta

5. Hadipratomo, W, Raharjo, P. P., (1985), Pengenalan Metode Elemen Hingga pada Teknik Sipil, Penerbit Nova, Bandung

6. Kosasih, P. B.,(2012), Teori dan Aplikasi Metode Elemen Hingga, Pnerbit Andi Yogyakarta, Yogyakarta

7. Purwono, R., Tavio, Imran, I., Raka, I G. P., (2007), Tata Cara Perhitungan Struktur Beton untuk Bangunan Gedung (SNI-03-2847-2002) Dilengkapi dengan Penjelasan (S-2002), ITS Press, Srabaya

8. Setiawan, A., (2015). Analisa Struktur, Penerbit Erlangga, Jakarta

9. Soemono, (1997), Ilmu Gaya Bangunan-bangunan Statis Tertentu, Penerbit Djambatan, Bandung

10. Wang, C. K. Salmon, C. G. S. Hariandja, B., (1987). Disain Beton Bertulang Jilid 1 dan Jilid 2, : Penerbit Erlangga, Jakarta

11. Wahyudi, L., Rahim, Syahril A.,(1997), Struktur Beton Bertulang Standar Baru SKNI T-15-1991-03, PT. Gramedia Pustaka Utama, Jakarta 